\title{
Accuracy of Ultrasonography Findings in Cases of Ocular Trauma
}

\author{
SARAH R.A. MOSTAFA, M.Sc.; BAHAA ELDEN A. ALI, M.D.; AZZA M. AHMED SAID, M.D. and \\ KHALID H. MAHMOUD, M.D.
}

The Department of Ophthalmology, Faculty of Medicine, Ain Shams University

\begin{abstract}
Background: The superficial location of the eye and its cystic composition make ultrasound ideal for imaging the eye. It is a simple, non ionizing, cost effective, real time imaging modality providing detailed cross sectional anatomy of the entire globe.
\end{abstract}

Aim of Study: To evaluate the accuracy of B-scan ultrasonography (US) in various types of ocular trauma by comparing the findings with the clinical examination and surgical findings if possible.

Patients and Methods: Descriptive analysis of cases of ocular trauma in patients who presented to Ophthalmology Department, Ain Shams University, in the period from November 2017 to May 2018 to compare clinical and surgical findings in those patients with the ultrasonography findings.

Results: Accuracy of US in the present study in prediction of post traumatic cataract was $80 \%$, lens dislocation was $83.64 \%$, vitreous hemorrhage was $100 \%$, PVD was $100 \%$, choroidal detachment was $100 \%$, partial retinal detachment was $96.4 \%$ and in detection of metallic IOFB was $100 \%$.

Conclusion: Ultrasound B-scan is an excellent, noninvasive, rapid diagnostic tool in assessing intraocular damage caused by blunt or penetrating eye injuries which most of the time renders ophthalmoscopy impossible due to opacification of light transmitting media. The images provide essential and detailed information about soft tissues damage, helping in the decision regarding early surgery, before chronic changes have occurred.

Key Words: Ultrasonography - Ocular trauma - CataractRetinal detachment-Vitreous hemorrhage.

\section{Introduction}

OCULAR trauma is defined as a lesion originated by concussion or open mechanisms over the ocular globe and its surrounding structures, which produces tissue damage in varying degree, temporarily or permanently compromising visual function [1]

Correspondence to: Dr. Sarah R.A. Mostafa, E-Mail: cold.hard56@gmail.com
Traumatic eye injuries involved about $3 \%$ of cases visited emergency departments of developing countries [2]. It is estimated that trauma causes blindness and visual impairment in many referees of ophthalmic emergency [3]. Such injuries can readily be investigated by ultrasound, which is of particular value when the light conducting media are opacified by hemorrhage or other injury [4] .

Most of these injuries are hard to diagnose in initial emergency department assessment. On the other hand, more frequent examinations to detect injuries may be hazardous for the patient [5].

Ultrasonography (US) can be safely performed in outdoor patient without any use of anaesthetics or sedative therapy. It is non-hazardous, atraumatic and valuable in the evaluation of orbito-ocular lesions, especially in the presence of opaque media and also of great help in the assessment of the orbit and outside the globe in case of ocular trauma [6] Ultrasound B-scan (brightness modulation) gives exceptionally detailed bidimensional images of the ocular structures [7].

In the emergency department, US proves to be more cost effective and a better screening tool for patients presenting with ocular trauma, specifically in low income countries and there is an excellent agreement between ultrasound findings and clinical diagnosis beyond chance is also in concurrence with other studies reported from different parts of the world [8].

Various studies have reported the diagnostic accuracy of US in the detection of different forms of ocular trauma in different populations. [7] reported the sensitivity and specificity of US in retinal detachment to be ranging between $97 \%$ $100 \%$ and $83 \%-100 \%$ respectively. 
Furthermore, for lens dislocation, [9] reported the sensitivity and specificity of US were $84.6 \%$ and $98.3 \%$, respectively.

\section{Aim of the work:}

To evaluate the accuracy of B-scan ultrasonography in various types of ocular trauma by comparing the findings with the clinical examination and surgical findings if possible.

\section{Patients and Methods}

Descriptive analysis of cases of ocular trauma in patients who presented to Ophthalmology Department, Ain Shams University, in the period from November 2017 to May 2018 to compare clinical and surgical findings in those patients with the ultrasonography findings.

\section{Inclusion criteria:}

Patients with history of ocular trauma either recent or old standing with or without opaque media recruited from Ophthalmology clinic.

\section{Exclusion criteria}

A- Uncooperative patients.

B- Patients with open globe injury not yet repaired.

Sampling method: Stratified sample.

Ethical considerations: Explanation of the procedure was done for all patients and a written informed consent was taken.

Study tools: All patients were evaluated by:

\section{1- Careful history taking including:}

- Name, age, gender, residency and which eye was affected by trauma.

- Time of trauma, its cause, date, place, time of presentation and the interval between the time of injury and time of presentation.

- Initial and final visual acuity (visual outcome following primary repair) and investigations done.

2- Ocular ultrasound examination (B-scan) using Sonomed machine E-Z scan 5500+, USA this was performed after ocular repair in recent cases and during follow-up in old cases of trauma.

\section{3- Full ophthalmological examination including:}

- Best corrected visual acuity measurement using snellen chart with conversion into $\log$. MAR notation for statistical analysis.
- External ocular examination to detect eyelid oedema, Laceration: Site and extent (lid margrin and canaliculi).

- Slit lamp examination of the globe:

- Closed globe injury for detection of: Conjunctival injuries, corneal intrastromal foreign body (FB), traumatic hyphema, lens injuries, choroidal rupture, vitreous haemorrhage, retinal damage, optic nerve damage.

- Open globe injury for detection of: Corneal wound with or without iris prolapse, limbal wound, and scleral wound with or without uveal prolapse, intra ocular foreign body (IOFB), perforating injuries.

- Posterior segment examination in cases of clear media.

4- Documentation of the surgical findings either during the primary repair in recent cases or during the secondary surgical interventions.

\section{Statistical analysis:}

Data were collected, revised, coded and entered to the Statistical Package for Social Science (IBM SPSS) version 23 . The quantitative data were presented as mean, standard deviations and ranges when parametric and median with inter-quartile range (IQR) when non parametric. Also qualitative variables were presented as number and percentages. So, the $p$-value was considered significant as the following: $p>0.05$ : Non significant (NS), $p<0.05$ : Significant $(\overline{\mathrm{S}}), p \leq 0.01$ : Highly significant (HS).

\section{Results}

The median age of our patients was 15.5 (range: 1.5-56), the majority of cases were from 11-20 years old. Sex distribution was $(73.3 \%)$ in males and $(26.7 \%)$ in females, most patients $(85 \%)$ presented within the first week, $(5 \%)$ attended from one week to one month and (10\%) presented after one month.

The injuries involving the right eye was (58.3\%) and in left eye was (41.7\%), geographical distribution of patients among study group study group were $(24 \%)$ in rural areas and $(76 \%)$ in urban, most of patients were workers of manual occupation in (43.3\%), students in $(38.3 \%)$ of patients followed by driver equal to housewives in $(6.7 \%)$, most of patients $(46.7 \%)$ had their trauma in the street, $(33.3 \%)$ in the work and $(20 \%)$ indoors.

Penetrating trauma was the most common type of trauma $(76.7 \%)$ while blunt trauma was in 
$(23.3 \%)$. Objects causing injury $(45 \%)$ were metal objects, $(11.7 \%)$ were wood, $(10 \%)$ stones, $(8.3 \%)$ glass, $(3.3 \%)$ shot gun (pellets), (1.7\%) knife, $(1.7 \%)$ quarrel and $(18.3 \%)$ were others as toys, pens, scissors or cat scratch.

\section{Clinical examination:}

BCVA in the present study was calculated through mean logMAR was $2.45 \pm 0.32 \mathrm{SD}$ ranged from 1.0 to 2.7. Corneal findings were corneal abrasions in $(5 \%)$, corneal central wounds in $(71.7 \%)$, corneal edema in $(8.3 \%)$, corneal opacity in $(10 \%)$, corneal FB in $(1.7 \%)$ and clear cornea in $(3.3 \%)$ of patients.

Anterior chamber depth and content in which showed hyphema in (30\%), inflammatory cells and membranes in $(15 \%)$, shallow anterior chamber in $(13.3 \%)$, free anterior chamber in $(18.3 \%)$, iris prolapse in $(11.7 \%)$, irregular anterior chamber in $(10 \%)$ and presence of vitreous in $(1.7 \%)$ of patients.

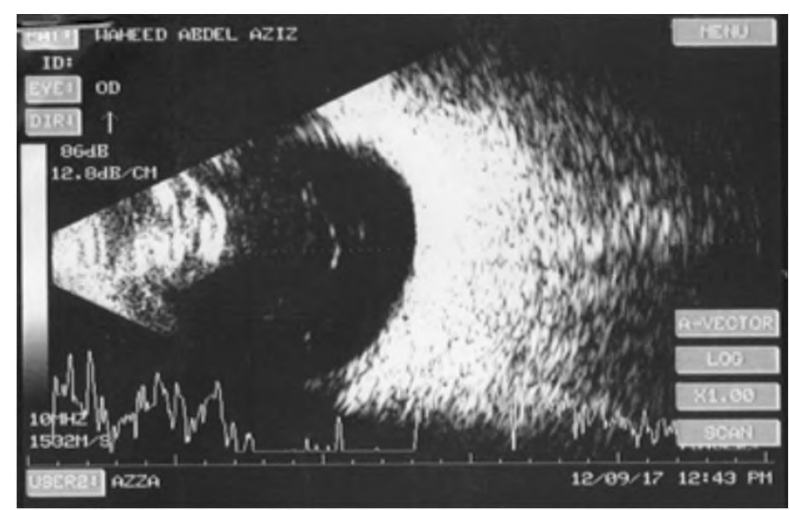

Fig. (1): US showing cataractous lens present in position in one of our patients.

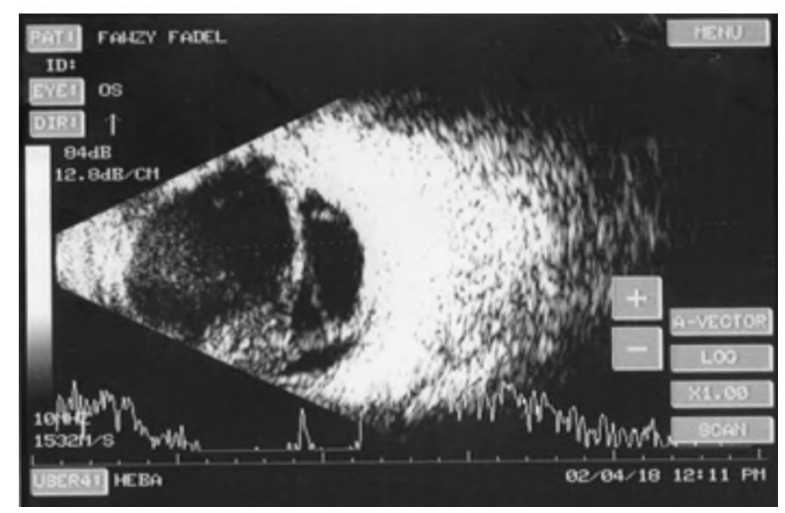

Fig. (3): US showing presence of post traumatic PVD in one of our patients.
Pupil was slightly reactive to light in (25\%), irregular shape in $(71.7 \%)$ and regular shape and reactive to light in $(3.3 \%)$. Lens clarity and position was clear lens in (18.3\%), lens opacity in (38.3\%), couldn't be assessed in $(36.7 \%)$, opened lens in $(3.3 \%)$ and aphakia was detected in $3.3 \%$.

Vitreous hemorrhage was detected in (14.5\%), PVD was detected in (40\%), Partial RD was detected in $(36 \%)$, posterior lens dislocation was in $(3 \%)$ and hazy view was in $(5 \%)$.

\section{US findings after ocular trauma:}

Post traumatic cataract as in (Fig. 1) was detected in $(49.1 \%)$, lens dislocation was detected in (16.4\%), Vitreous hemorrhage (Fig. 2) was detected in $(94.5 \%)$, PVD (Fig. 3) was detected in (41.8\%), choroidal detachment was detected in $(9.1 \%)$, Partial RD (Fig. 4) was detected in (29.1\%) and $\mathrm{FBB}$ (Fig. 5) was detected in (18.2\%) of patients.

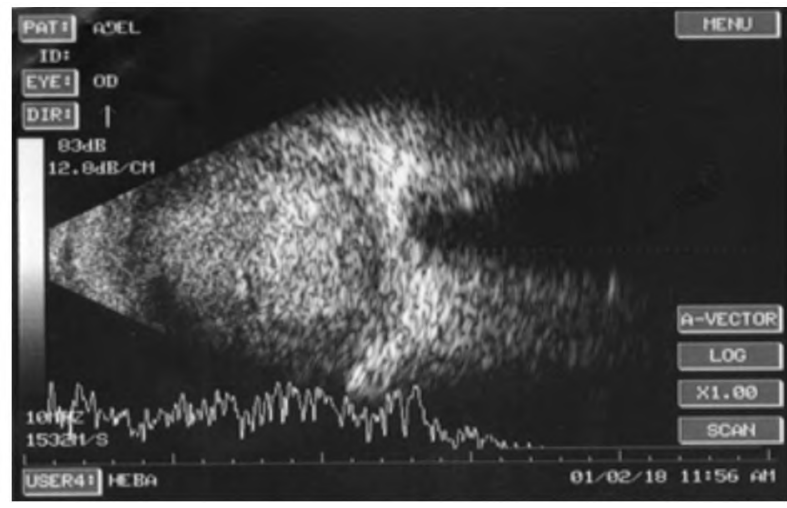

Fig. (2): US showing vitreous hemorrhage in one of our patients.

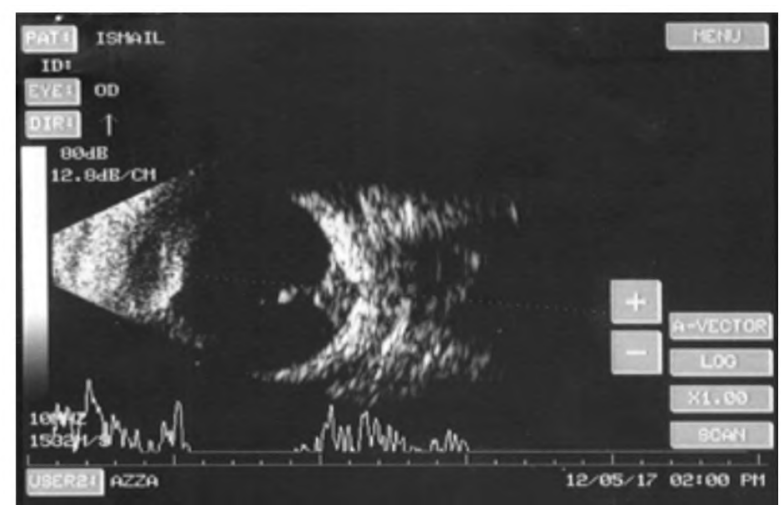

Fig. (4): US showing presence of vitreous hemorrhage with tractional RD (white arrow) in one of our patients. 


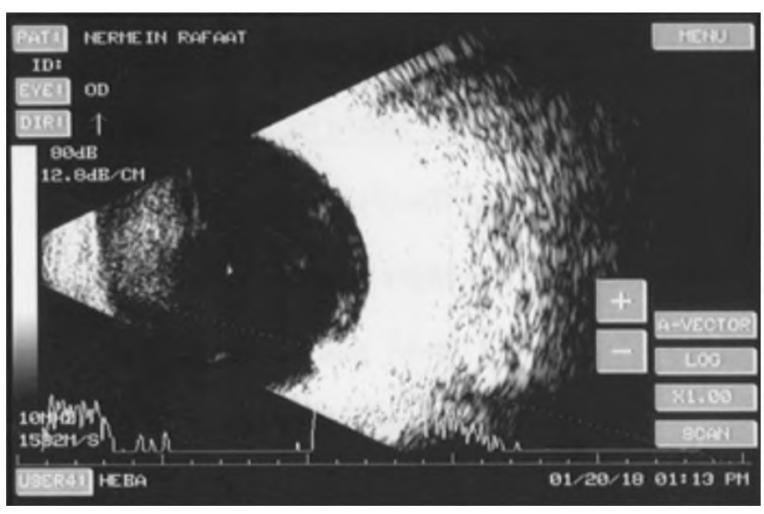

Fig. (5): US showing metallic IOFB in one of our patients.

\section{Type of second surgery:}

Vitrectomy + silicon oil injection + IOL implantation were done in $(41.7 \%)$, vitrectomy + silicon oil injection were done in $(25 \%)$, IOL implantation was done in $(23.3 \%)$, evisceration was performed in $(8.3 \%)$, intra vitreal injection of antibiotics was done in $(1.7 \%)$ of the patients.

Findings in second surgery of ocular trauma Tables (2,3).

Post traumatic cataract was detected in $(50.9 \%)$, lens dislocation was detected in $(29.1 \%)$, Vitreous hemorrhage was detected in (94.5\%), PVD was detected in $(41.8 \%)$, choroidal detachment was detected in $(9.1 \%)$, Partial RD was detected in
$(32.7 \%)$ and IOFB was detected in $(18.2 \%)$ of patients.

In the present study US sensitivity, specificity and accuracy in detection of ocular findings in trauma were as follows (Table 4):

- Post traumatic cataract:Accuracy was $80 \%$, sensitivity $78.6 \%$ and specificity $81.5 \%$.

- Detection of lens dislocation: Accuracy was $83.6 \%$, sensitivity was $50 \%$ and specificity was $97.4 \%$.

- Presence of vitreous hemorrhage: Accuracy was $100 \%$, sensitivity $100 \%$ and specificity $100 \%$.

- Presence of PVD: Accuracy was $100 \%$, sensitivity $100 \%$ and specificity $100 \%$.

- Choroidal detachment: Accuracy was $100 \%$, sensitivity $100 \%$ and specificity $100 \%$.

- Partial retinal detachment:Accuracy was $96.4 \%$, sensitivity $88.9 \%$ and specificity $100 \%$.

- Presence of metallic IOFB: Accuracy was 100\%, sensitivity $100 \%$ and specificity $100 \%$.

Ocular US can be used to diagnose choroidal detachment, RD, PVD, vitreous hemorrhage and metallic IOFB with a high degree of accuracy. The fundamental utility of US and its speed, noninvasive nature and cost-effectiveness suggest that it is an ideal tool for busy emergency medicine clinicians.

Table (1): Findings of clinical examination compared to that appeared in US examination.

\begin{tabular}{|c|c|c|c|c|c|c|c|}
\hline & \multicolumn{2}{|c|}{$\begin{array}{c}\text { Clinical } \\
\text { examination }\end{array}$} & \multicolumn{2}{|c|}{$\mathrm{U} / \mathrm{S}$} & \multirow{2}{*}{$\begin{array}{c}\text { Test } \\
\text { value }\end{array}$} & \multirow{2}{*}{$\begin{array}{c}p- \\
\text { value }\end{array}$} & \multirow[t]{2}{*}{ Sig. } \\
\hline & No. & $\%$ & No. & $\%$ & & & \\
\hline $\begin{array}{l}\text { Post traumatic cataract: } \\
\text { Not detected } \\
\text { Detected }\end{array}$ & $\begin{array}{l}34 \\
26\end{array}$ & $\begin{array}{l}56.7 \\
43.3\end{array}$ & $\begin{array}{l}28 \\
27\end{array}$ & $\begin{array}{l}50.9 \\
49.1\end{array}$ & 0.383 & 0.536 & NS \\
\hline $\begin{array}{l}\text { Lens dislocation: } \\
\text { Not detected } \\
\text { Detected }\end{array}$ & $\begin{array}{l}58 \\
2\end{array}$ & $\begin{array}{l}96.6 \\
3.3\end{array}$ & $\begin{array}{l}46 \\
9\end{array}$ & $\begin{array}{l}83.6 \\
16.4\end{array}$ & 3.965 & 0.046 & $S$ \\
\hline $\begin{array}{l}\text { Vitreous hemorrhage: } \\
\text { Not detected } \\
\text { Detected }\end{array}$ & $\begin{array}{l}51 \\
9\end{array}$ & $\begin{array}{l}85.0 \\
15.0\end{array}$ & $\begin{array}{l}3 \\
52\end{array}$ & $\begin{array}{l}5.5 \\
94.5\end{array}$ & 72.899 & 0.000 & HS \\
\hline $\begin{array}{l}\text { Posterior retinal detachment: } \\
\text { Not detected } \\
\text { Detected }\end{array}$ & $\begin{array}{l}58 \\
2\end{array}$ & $\begin{array}{l}96.7 \\
3.3\end{array}$ & $\begin{array}{l}32 \\
23\end{array}$ & $\begin{array}{l}58.2 \\
41.8\end{array}$ & 24.981 & 0.000 & HS \\
\hline $\begin{array}{l}\text { Choroidal detachment: } \\
\text { Not detected } \\
\text { Detected }\end{array}$ & $\begin{array}{l}60 \\
0\end{array}$ & $\begin{array}{l}100.0 \\
0.0\end{array}$ & $\begin{array}{l}50 \\
5\end{array}$ & $\begin{array}{l}90.9 \\
9.1\end{array}$ & 5.702 & 0.016 & $S$ \\
\hline $\begin{array}{l}\text { Partial retinal detachment: } \\
\text { Not detected } \\
\text { Detected }\end{array}$ & $\begin{array}{l}47 \\
13\end{array}$ & $\begin{array}{l}78.3 \\
21.7\end{array}$ & $\begin{array}{l}39 \\
16\end{array}$ & $\begin{array}{l}70.9 \\
29.1\end{array}$ & 0.839 & 0.359 & NS \\
\hline $\begin{array}{l}\text { Metallic IOFB: } \\
\text { Not detected } \\
\text { Detected }\end{array}$ & $\begin{array}{l}59 \\
1\end{array}$ & $\begin{array}{l}98.3 \\
1.7\end{array}$ & $\begin{array}{l}45 \\
10\end{array}$ & $\begin{array}{l}81.8 \\
18.2\end{array}$ & 9.048 & 0.002 & HS \\
\hline
\end{tabular}


Table (2): US results of examination compared to findings of second surgery.

\begin{tabular}{|c|c|c|c|c|c|c|c|}
\hline & \multicolumn{2}{|c|}{$\mathrm{U} / \mathrm{S}$} & \multicolumn{2}{|c|}{$\begin{array}{l}\text { Surgeon in } \\
\text { 2nd surgery }\end{array}$} & \multirow{2}{*}{$\begin{array}{c}\text { Test } \\
\text { value }\end{array}$} & \multirow{2}{*}{$\begin{array}{c}p- \\
\text { value }\end{array}$} & \multirow[t]{2}{*}{ Sig. } \\
\hline & No. & $\%$ & No. & $\%$ & & & \\
\hline \multicolumn{8}{|c|}{ Post traumatic cataract: } \\
\hline Not detected & 28 & 50.9 & 27 & 49.1 & 0.036 & 0.849 & NS \\
\hline Detected & 27 & 49.1 & 28 & 50.9 & & & \\
\hline \multicolumn{8}{|l|}{ Lens dislocation: } \\
\hline Not detected & 46 & 83.6 & 39 & 70.9 & 2.536 & 0.111 & NS \\
\hline Detected & 9 & 16.4 & 16 & 29.1 & & & \\
\hline \multicolumn{8}{|c|}{ Vitreous hemorrhage: } \\
\hline Not detected & 3 & 5.5 & 3 & 5.5 & 0.000 & 1.000 & NS \\
\hline Detected & 52 & 94.5 & 52 & 94.5 & & & \\
\hline \multicolumn{8}{|l|}{$P V D:$} \\
\hline Not detected & 32 & 58.2 & 32 & 58.2 & 0.000 & 1.000 & NS \\
\hline Detected & 23 & 41.8 & 23 & 41.8 & & & \\
\hline \multicolumn{8}{|c|}{ Choroidal detachment: } \\
\hline Not detected & 50 & 90.9 & 50 & 90.9 & 0.000 & 1.000 & NS \\
\hline Detected & 5 & 9.1 & 5 & 9.1 & & & \\
\hline \multicolumn{8}{|c|}{ Partial retinal detachment: } \\
\hline Not detected & 39 & 70.9 & 37 & 67.3 & 0.170 & 0.680 & NS \\
\hline Detected & 16 & 29.1 & 18 & 32.7 & & & \\
\hline \multicolumn{8}{|l|}{ Metallic IOFB: } \\
\hline Not detected & 45 & 81.8 & 45 & 81.8 & 0.000 & 1.000 & NS \\
\hline Detected & 10 & 18.2 & 10 & 18.2 & & & \\
\hline
\end{tabular}

Table (3): Clinical examination results compared to findings of second surgery.

\begin{tabular}{|c|c|c|c|c|c|c|c|}
\hline & \multicolumn{2}{|c|}{$\begin{array}{c}\text { Clinical } \\
\text { examination }\end{array}$} & \multicolumn{2}{|c|}{$\begin{array}{l}\text { Surgeon in } \\
\text { 2nd surgery }\end{array}$} & \multirow{2}{*}{$\begin{array}{c}\text { Test } \\
\text { value }\end{array}$} & \multirow{2}{*}{$\begin{array}{c}p- \\
\text { value }\end{array}$} & \multirow[t]{2}{*}{ Sig. } \\
\hline & No. & $\%$ & No. & $\%$ & & & \\
\hline \multicolumn{8}{|c|}{ Post traumatic cataract: } \\
\hline Not detected & 34 & 56.7 & 27 & 49.1 & 0.661 & 0.416 & NS \\
\hline Detected & 26 & 43.3 & 28 & 50.9 & & & \\
\hline \multicolumn{8}{|l|}{ Lens dislocation: } \\
\hline Not detected & 57 & 95.0 & 39 & 70.9 & 12.075 & 0.001 & HS \\
\hline Detected & 3 & 5.0 & 16 & 29.1 & & & \\
\hline \multicolumn{8}{|c|}{ Vitreous hemorrhage: } \\
\hline Not detected & 51 & 85.0 & 3 & 5.5 & 72.899 & 0.000 & HS \\
\hline Detected & 9 & 15.0 & 52 & 94.5 & & & \\
\hline \multicolumn{8}{|c|}{ Posterior retinal detachment: } \\
\hline Not detected & 58 & 96.7 & 32 & 58.2 & 24.981 & 0.000 & HS \\
\hline Detected & 2 & 3.3 & 23 & 41.8 & & & \\
\hline \multicolumn{8}{|c|}{ Choroidal detachment: } \\
\hline Not detected & 60 & 100.0 & 50 & 90.9 & 5.702 & 0.016 & $S$ \\
\hline Detected & 0 & 0.0 & 5 & 9.1 & & & \\
\hline \multicolumn{8}{|c|}{ Partial retinal detachment: } \\
\hline Not detected & 47 & 78.3 & 37 & 67.3 & 1.783 & 0.181 & NS \\
\hline Detected & 13 & 21.7 & 18 & 32.7 & & & \\
\hline \multicolumn{8}{|l|}{ Metallic IOFB: } \\
\hline Not detected & 59 & 98.3 & 45 & 81.8 & 9.048 & 0.002 & HS \\
\hline Detected & 1 & 1.7 & 10 & 18.2 & & & \\
\hline
\end{tabular}


Table (4): Diagnostic accuracy of U/S in prediction of second surgery results.

\begin{tabular}{llllllllll}
\hline & TP FP TN FN & Sensitivity & Specificity & PPV & NPV & Accuracy \\
\hline Post Traumatic Cataract & 22 & 5 & 22 & 6 & $78.6 \%$ & $81.5 \%$ & $81.48 \%$ & $78.57 \%$ & $80.0 \%$ \\
Lens Dislocation & 8 & 1 & 38 & 8 & $50.0 \%$ & $97.4 \%$ & $88.89 \%$ & $82.61 \%$ & $83.64 \%$ \\
Vitreous Hemorrhage & 52 & 0 & 3 & 0 & $100.0 \%$ & $100.0 \%$ & $100.0 \%$ & $100.0 \%$ & $100.0 \%$ \\
PVD & 23 & 0 & 32 & 0 & $100.0 \%$ & $100.0 \%$ & $100.0 \%$ & $100.0 \%$ & $100.0 \%$ \\
Choroidal Detachment & 5 & 0 & 50 & 0 & $100.0 \%$ & $100.0 \%$ & $100.0 \%$ & $100.0 \%$ & $100.0 \%$ \\
Partial Retinal Detachment & 16 & 0 & 37 & 2 & $88.9 \%$ & $100.0 \%$ & $100.0 \%$ & $94.87 \%$ & $96.4 \%$ \\
Metallic IOFB & 10 & 0 & 45 & 0 & $100.0 \%$ & $100.0 \%$ & $100.0 \%$ & $100.0 \%$ & $100.0 \%$ \\
\hline TP: True positive. & FP & : False positive. & & & TN : True negative. & \\
FN: False negative. & PPV : Positive predictive value. & & & & &
\end{tabular}

\section{Discussion}

US evaluation of the eye and orbit has become an essential component of clinical ophthalmology. US is a sensitive and accurate technique with some advantages over conventional radiographic techniques, such as absence of ionizing radiation and visualization of soft tissue structures [11].

Ocular trauma with an associated media opacity involving the cornea and/or the lens would require US in order to have a complete evaluation of the globe and to institute appropriate medical and/or surgical treatment. B-scan US can demonstrate the presence and density of vitreous hemorrhage as well as aid in the diagnosis of retained intraocular foreign bodies [10]

Trauma is one of the most common reasons of lens dislocation [12]. The fast diagnosis of such an injury can be greatly help improving the patients' outcomes. Diagnostic accuracy of US in assessment of traumatic lens dislocation is evaluated in a few studies. Whereas some of investigations suggested CT scan of the orbit as an accurate method [13], others consider US as a valuable diagnostic tool in detection of lens dislocation, especially in lack of CT scan of the orbit $[5,14]$.

There are a few study assessed the diagnostic value of US in detection of lens dislocation [13] revealed that sensitivity and specificity of US are $75 \%$ and $97.9 \%$ in diagnosis of lens dislocation, respectively.

IOFB represent a subset of ocular injuries that present complex surgical challenges to remove the IOFB successfully while attempting to preserve vision and restore ocular architecture [15]. In the present study the detection of metallic IOFBby US had an accuracy of $100 \%$, sensitivity of $100 \%$ and specificity of $100 \%$ and these were comparable to the previous studies.
Accurate preoperative evaluation of these eyes is important to plan surgical approaches and to determine the prognosis in these cases. For many years, diagnostic US has been used as the principle method to evaluate the posterior segment of traumatized eye with opaque media [15]

The accuracy of sonography in detection of IOFB was $100 \%$ and localization was also correlated by the intraoperative findings. In the same manner, US had high sensitivity and specificity in detection of associated problems such as vitreous hemorrhage [16] which was comparable to the present result. US is lack of enough capacity to demonstrate the texture of foreign body which was definitely determined intraoperatively [17] .

PVDs occur as a result of separation of the posterior part of the vitreous from the retina, whose appearance depends on the extent of the detachment. The hyaloid membrane that separates from the retina is not likely to move with eye movements. Taken together, these observations suggest that imaging technique plays a role in differentiating retinal detachment from other posterior chamber abnormalities [14]. In the present study the presence of post vitreous detachment (PVD) was detected by US with accuracy of $100 \%$, sensitivity of $100 \%$ and specificity of $100 \%$ and these were comparable to the previous studies.

This was supported by the results of [18] who found that all patients who were misidentified as having RDs in fact had vitreous hemorrhages, $80 \%$ of whom also had concomitant vitreous detachments. Despite this potential limitation, diagnostic test characteristics were consistent. In the present study the presence of vitreous hemorrhage by US had an accuracy of $100 \%$, sensitivity of $100 \%$ and specificity of $100 \%$ and these were comparable to the previous studies. 
The most impressive diagnostic results came from [14] who diagnosed retinal detachments with $100 \%$ sensitivity and specificity.

The trials by 18 also reported high sensitivities and specificities for the detection of retinal detachment. Unlike the study by [14] expertise.

[7] reported the sensitivity and specificity of US in RD to be ranging between $97 \%-100 \%$ and 83\%-100\% respectively [10]. Furthermore, for lens dislocation, [9] reported the sensitivity and specificity of US were $84.6 \%$ and $98.3 \%$ respectively. In the present study US in detection of partial retinal detachment: Accuracy was $96.4 \%$, sensitivity $88.9 \%$ and specificity $100 \%$ and these were comparable to the previous studies.

[19] found the US to be sensitive in 73\%, specific in $90 \%$, and [13] reported US to have $84.6 \%$ sensitivity and $96.5 \%$ specificity for detecting vitreous haemorrhage. $100 \%$ sensitivity of ultrasound B scan, while 97 specificity in diagnosing foreign body due to ocular trauma to detect majority of the cases.

Another study by [20] revealed $93 \%$ sensitivity of US for all kind of intraocular foreign bodies including metallic and non-metallic. The main impediment in clinical detection of foreign body in a traumatized eye is small size, limited patient's compliance, optical media haziness and concealed location.

An excellent agreement between US findings and clinical diagnosis beyond chance is also in concurrence with other studies reported from different parts of the world [14]. The findings of this study were comparable to those of two other large series assessing ocular injuries by US B-scan. Both studies showed diagnostic accuracy of greater than $90 \%$.

In the present study US in detection of post traumatic cataract had an accuracy of $80 \%$, sensitivity of $78.6 \%$ and specificity of $81.5 \%$, detection of lens dislocation had an accuracy of $83.6 \%$, sensitivity of $50 \%$ and specificity of $97.4 \%$, presence of vitreous hemorrhage had an accuracy of $100 \%$, sensitivity of $100 \%$ and specificity of $100 \%$, presence of post vitreous detachment (PVD) had an accuracy of $100 \%$, sensitivity of $100 \%$ and specificity of $100 \%$, choroidal detachment had an accuracy of $100 \%$, sensitivity of $100 \%$ and specificity of $100 \%$, partial retinal detachment had an accuracy of $96.4 \%$, sensitivity of $88.9 \%$ and specificity of $100 \%$, presence of metallic intraocular foreign body (IOFB) had an accuracy of $100 \%$, sensitivity of $100 \%$ and specificity of $100 \%$.

\section{Conclusion:}

B-scan US is an excellent, non-invasive, rapid diagnostic tool in assessing intraocular damage caused by blunt or penetrating eye injuries which most of the time renders ophthalmoscopy impossible due to opacification of light transmitting media.

It shows high sensitivity, specificity and accuracy in detection of vitreous hemorrhage, PVD, choroidal detachment, RD and metallic IOFB however, it shows moderate sensitivity, specificity and accuracy in detection of post traumatic cataract and moderate sensitivity in detection of lens dislocation.

\section{References}

1- ERIKITOLA O.O., SHAHID S.M., WAQAR S. and HEWICK S.A.: Ocular trauma classification, management and prognosis. Br. J. Hosp. Med. Lond., 74: 108-111, 2013.

2- KUBAL W.S.: Imaging of Orbital Trauma. Radiographics, 28: 1729-1739, 2008.

3- McCLENAGHAN F.C., EZRA D.G. and HOLMES S.B.: Mechanisms and management of vision loss following orbital and facial trauma. Curr. Opin. Ophthalmol., 22: 426- 431, 2011.

4- PARCHAND S., SINGH R. and BHALEKAR S.: Reliability of ocular ultrasonography findings for pre-surgical evaluation in various vitreo-retinal disorders. Semin. Ophthalmol., 29: 236 -241, 2014.

5- SILVERMAN R.H.: High-resolution ultrasound imaging of the eye-a review. Clin. Experiment. Ophthalmol., 37: 54- 67, 2009.

6- ETHLERS J.P. and PUODZIUVIENE: Ultrasound value in diagnosis, management and prognosis of severe eye injuries, 3 (56): 1392-2114, 2005.

7- VRABLIK M.E., SNEAD G.R., MINNIGAN H.J., KIRSCHNER J.M., EMMETT T.W. and SEUPAUL R.A.: The diagnostic accuracy of bedside ocular ultrasonography for the diagnosis of retinal detachment: A systematic review and meta-analysis. Ann. Emerg. Med., 65: 199203, 2015 .

8- RABINOWITZ R., YAGEV R., SHOHAM A. and LIFS HITZ T.: Comparison between clinical and ultrasound findings in patients with vitreous hemorrhage. Eye (Lond)., 18 (3): 253-256, 2004

9- HAGHIGHI S.H.O., BEGI H.R.M., SORKHABI R., TARZAMANI M.K., ZONOUZ G.K., MIKAEILPOUR A. and RAHMANI F.: Diagnostic accuracy of ultrasound in detection of traumatic lens dislocation. Emerg. (Tehran)., 2: 121-124, 2014.

10- COLEMAN D.S., DALY S.W., ATENCIO A., LLOYED A.O. and SILVERMAN R.H.: Ultrasonic evaluation of vitreous and retina. Semin. Ophthalmol., 210-218, 1998. 
11- PAVLIN C.J., HARASIEWICZ K., SHERAR M.D. and FOSTER F.S.: Clinical use of ultrasound biomicroscopy. Ophthalmology, 98: 287-295, 1991.

12- WANG R., BI C.C., LEI C.L., SUN W.T., WANG S.S. and DONG X.J.: Multiple methods of surgical treatment combined with primary IOL implantation on traumatic lens subluxation/dislocation in patients with secondary glaucoma. Int. J. Ophthalmol., 7: 264- 272, 2014.

13- IMRAN S., AMIN S. and DAULA M.I.H.: Imaging in Ocular Trauma Optimizing the Use of Ultrasound and Computerised Tomography. Pak. J. Ophthalmol., 27 (3): 146-151, 2011.

14- BLAIVAS M., THEODORO D. and SIERZENSKI P.R.: Lens Dislocation. A Study of Bedside Ocular Ultrasonography in the Emergency Department. Acad. Emerg. Med., 9: 791-799, 2002

15- MCNICHOLAS M.M., BROPHY D.P., POWER W.J. and GRIFFIN J.F.: Ocular trauma: evaluation with ultrasound. Radiology, 195: 423- 427, 1995.

16- GLASIER C.M., BRODSKY M.C. and LEITHISER R.E.:
High resolution ultrasound with Doppler: A diagnostic adjunct in orbital and ocular lesions. Pediatric Radiology, 22: 174-178, 1992

17- DEVANG M.G., CLAUDIA F.K. and JEFFREY L.: Radiologic differentiation of intraocular glass: Evaluation of imaging techniques, glass types, size, and effect of intraocular hemorrhage. AJR. Am. J. Roentgenol., 177: 1199-1203, 2001

18- YOONESSI R., HUSSAIN A. and JANG T.B.: Bedside ocular ultrasound for the detection of retinal detachment in the emergency department. Acad. Emerg. Med., 17: 913-917, 2010.

19- KIM S. and LEE S.: Comparison of ultrasound and intraoperative finding in patients with vitreous hemorrhage. Investigative Ophthalmol. Visual. Sci., 46 (13): 5436, 2005 .

20- ULLAH A., KHAN B.S., ALAM M. and KHAN M.D.: Ambulatory cataract surgery IN public health sector in NWFP: A study of 302 cases. J. Postgraduate. Medical Institute (Peshawar-Pakistan), 20 (3): 272-278, 2006

\section{دقة نتائج الهوجات فوق الصوتية فى حالات إصابات العين}

$$
\begin{aligned}
& \text { إن الهدف من إجراء هذه الدراسة هو تقييم دقة التصوير بالموجات فوق الصوتية للعين في إصابات العين عن طريق مقارنة النتائج مع } \\
& \text { الفحص السريرى والنتائج الجراحية إن أمكن. }
\end{aligned}
$$

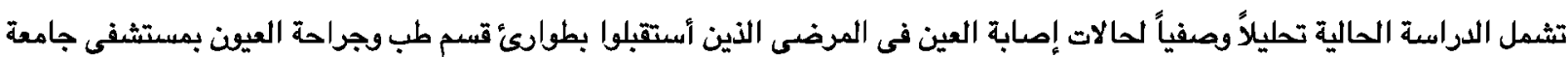

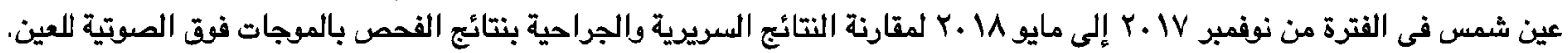

$$
\begin{aligned}
& \text { شملت الدراسة المرضى الذين تعرضوا لإصابات قديمة بالعين وتحت المتابعة بعيادة طب وجراحة العيفن عدد المرضى التى شملتهم } \\
& \text { الدراسة .7 مريضاً. } \\
& \text { طرق البحث: تم تقييم جميع المرضى كالتالى: }
\end{aligned}
$$

النتائج: وجد أن متوسط العمر فى هؤلاء المرضى هوحوالى ه.0 اويتراوح ما بين ـ1ـاه سنة، وكانت غالبية حالات الأصابات من عمر 


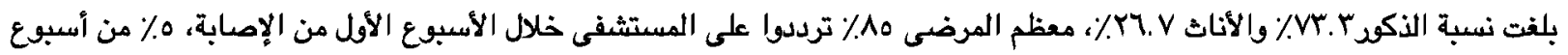
الأول من الشهر الأول، ـ1\% بعد شهر من الإصابة.

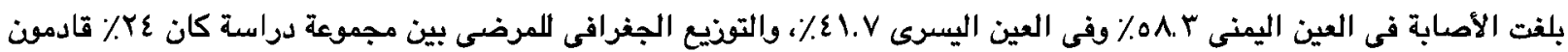

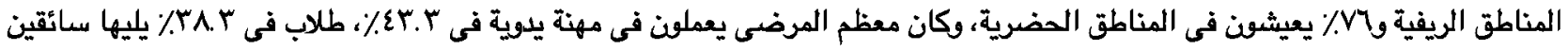

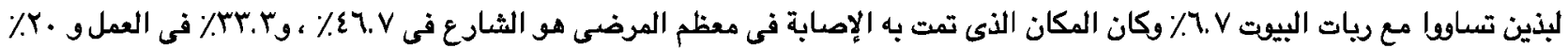
في داخل المنزل.

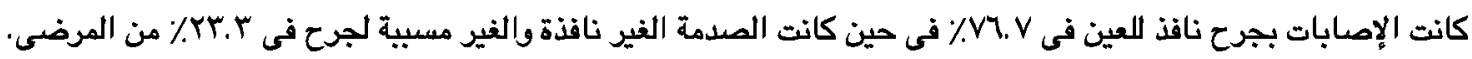

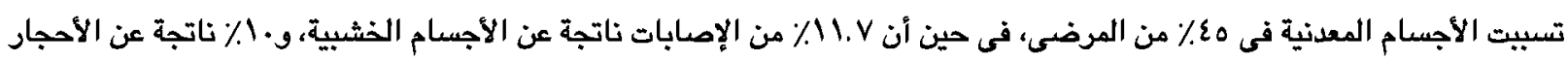

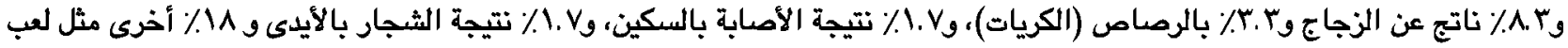

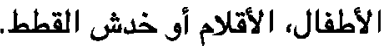

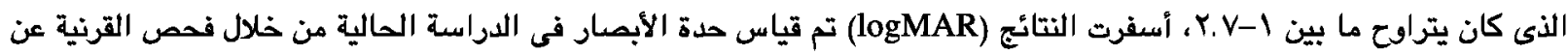

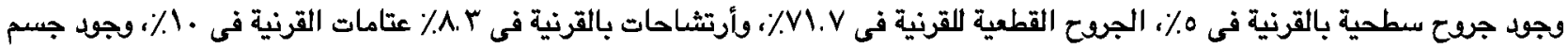

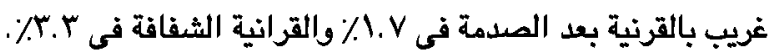

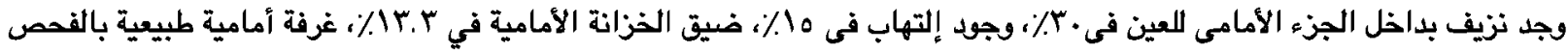

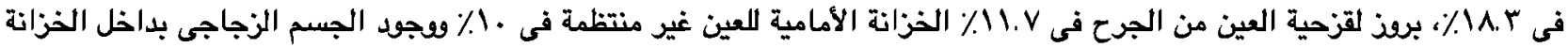

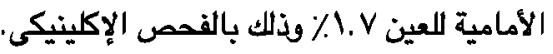

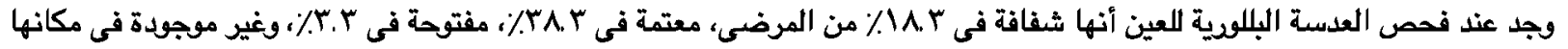

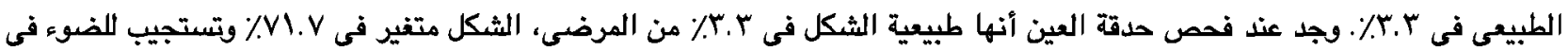

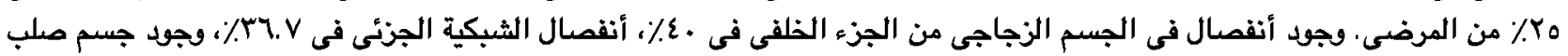

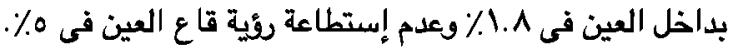

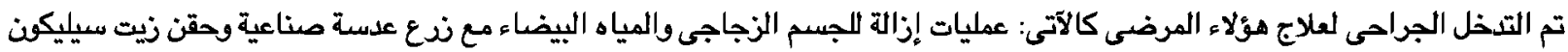

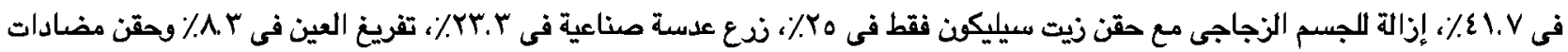

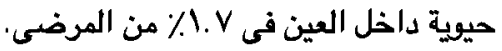

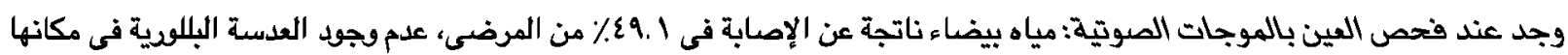

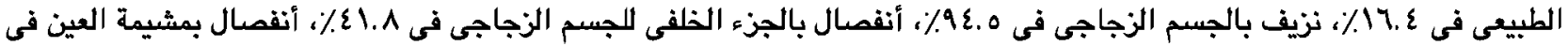

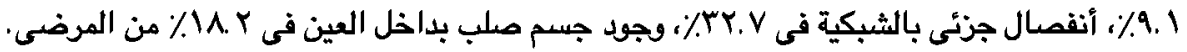

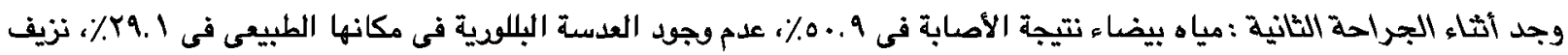

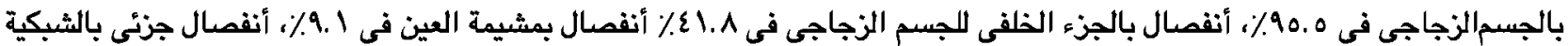

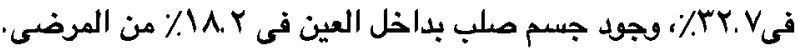
تم الكثف في هذه الدراسة عن دقة وحساسية وخصوصية جهاز الموجات فوق الصوتية لإصابات العين كالتالى:

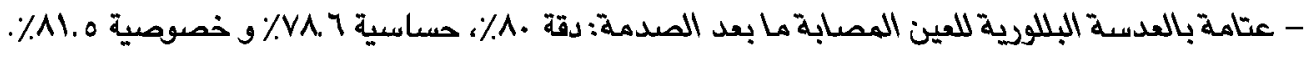

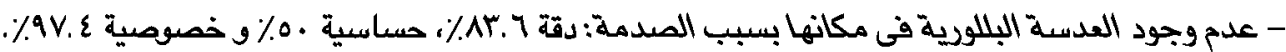

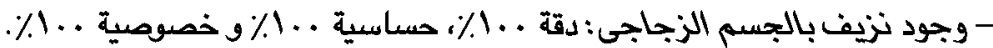

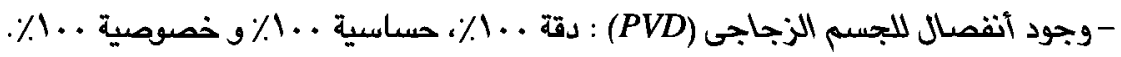

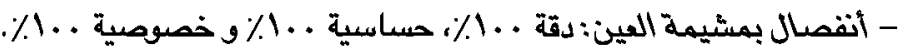

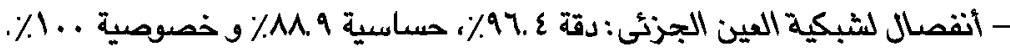

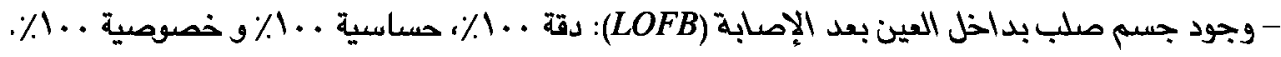

